\title{
NATIONAL INTEREST, FREEDOM OF EXPRESSION AND THE NIGERIAN PRESS IN CONTEMPORARY DEMOCRATIC CONTEXT
}

\author{
Aondover Eric Msughter ${ }^{1}$ \\ Hamza A. Pate ${ }^{2}$
}

\section{Introduction}

In Nigeria, apart from the executive, the judiciary and the legislature, the media are regarded as the Fourth Estate of the Realm. Article ig of the Universal Declaration of Human Right provides freedom of expression as part of fundamental human rights. At the level of the African Union (AU), the right to freedom of information and freedom of expression is also recognized. The Nigerian Constitution of 1999 (as amended) equally guarantees the freedom of expression, specifically Section 39 of the Constitution which assigns a constitutional right, power, role, obligation and duty to the press. Nigerian Constitutions since then have upheld this role. Section 22 of the same Constitution recognises the media as the "Fourth Estate of the Realm". It therefore means that the media oversees the government and its agencies, thereby keeping them on their toes. The Freedom of Information Act establishes that information should be made available and that citizens should feel free to express their personal views. In order to achieve the objectives of this paper, the major question to consider is: How potent is the Nigerian media as watchdogs of the society as far as freedom of expression is concerned? Data

I Department of Mass Communication, Bayero University. Kano, Nigeria. E-mail: aondover7@gmail.com. ORCID: http://orcid.org/0000-0002-526I-987I

2 Department of Management Technology, Modibbo Adama University of Technology. Yola, Nigeria. E-mail: hamzapate@ymail.com. ORCID: https://orcid.org/oooo-ooo3-Ioo6-3577 
analyzed in this paper include pertinent judicial decisions contained in law reports and journals, technical documents, and non-legal sources.

The United Nations has established May $3^{\text {rd }}$ as World Press Freedom Day, in recognition of the contributions of the media to national and global development. In his statement on World Press Freedom Day, President George W. Bush (2008) mentioned that press freedom was enshrined in the First Amendment to the Constitution of the United States of America. The former American President Thomas Jefferson declared that if he had a choice, he would prefer media without government than government without the media (Akinwale 20I0). The press is a vibrant institution which provides platforms for power negotiations in the public space. They set the stage for public discourse on popular issues. Iredia (20I5) established that the immense contribution of the media to the success of the struggle for independence in Nigeria, the heroic role it also played in bringing the military dictatorship in the country to an end, and its unending quest since the return to democracy in I999 to make the country's government accountable to the Nigerian people are issues which underscore the pragmatic posture of the Nigerian media in its nation's development process. By their professional calling, Pate (20I7) added that journalists should enjoy autonomy, independence, flexibility and ease for credible operations.

\section{The Context}

According to Pate (20I7), the challenge of freedom of expression remains daunting for all countries and especially for Nigeria with its large population of I98.8 Million people, 400+ ethnic groups, two major religions, dozens of political parties, 36 federating states and additional complex platforms of diversities. The Nigerian multicultural setting is characterized by diversity, heterogeneity and pluralism in the cultures, orientations and attitudes of the people (Pate 20I7).

Nwanne (20I4) is of the view that Nigeria is not yet a free and open society, despite the availability of diverse viewpoints flowing from a remarkable abundance of press organisations in the country. However, several press organizations in Nigeria lack complete freedom due to censorship, the multiple existing power centres and volatile political institutions. In spite of the proliferation of press organizations, constitutional provisions for press freedom have not been fully enforced. Empirical evidence presented by Iredia (20I5) shows that no other group has played a more crucial role than the 
media in the struggle for Nigeria's independence. He argued that the great leaders of the nationalist movements in Africa, and other political activists, recognized the immense power of the media. In Nigeria, the colonial press was spear-headed by leaders of nationalist movements like Herbert Macaulay, Nnamdi Azikiwe, Ernest Ikoli, Obafemi Awolowo, Anthony Enahoro and Ibrahim Imman who, according to Jibo and Simbine (2003), used the press to fight gallantly to challenge the basis of colonial rule so as to liberate Nigerians from that yoke. The attainment of independence was thus largely due to the media.

In the I999 Nigerian Constitution, Section 39, Sub-section I, it is stated that "Every person shall be entitled to freedom of expression, including freedom to hold opinion and to receive and impart ideas and information without interference". However, Oboh (20I8) articulated that the claim by the Nigerian journalists of having press freedom is not correct. He argued that the rights that the Nigerian journalists have to report on events and issues in society are the same right other Nigerians have just for being citizens. Pointing that, the 1999 Nigerian Constitution, Section 39, Sub-Section 3, stated that, "Nothing in this section (section 39) shall invalidate any law in the Constitution that is reasonably justifiable in a democratic society".

The implication of sub-section 3 in section 39 of the 1999 Nigerian Constitution is that journalists have no entitlements to any right in the Constitution that is not available to other citizens. For example, it is unethical for journalists to disclose the sources of their information. But it will amount to Contempt of Court in Nigeria for a journalist to withhold information from a judge that would enable him or her to deliver justice on a case forming the basis of a judicial enquiry. This is because journalists have no legal entitlements protecting them against anti-press provisions in the 1999 Nigerian Constitution, unlike the US Constitution where journalists cannot be compelled by the judiciary to disclose the sources of their information. Pate and Idris (20I7, I37-I38) noted that the "Constitution did not accord journalists specified safety and protection framework, except that of every citizen, all journalists in principle benefit from the right to life and the prohibition against forced disappearance and torture".

The media can rely on the provision of freedom of speech in section 39(I) of the Constitution, which provides that every person shall be entitled to freedom of expression, including freedom to hold opinions and to receive and impart ideas and information without interference. Proper scrutiny of this provision as presented in this paper, however, shows that it is not about press freedom but freedom of speech. To argue that media professionals are 
citizens, and are therefore covered by the general provision on freedom of speech which is available to all is simplistic. In any case, there is evidence that the Constitution itself does not see the media and the public as one; hence, it assigned functions to the general public before isolating the media for its own mandate. Section I3 of the Constitution provides that everyone, including all organs of government and all authorities and persons exercising legislative, executive or judicial powers, shall conform to, observe and apply the provisions of Chapter 2 of the Constitution. To further reiterate, down the line of section 22 the media is presented as a body upon whom the observance of the provisions of the chapter rests to differentiate the media from the general public. Having, thus, effected such differentiation, the media should not be expected to derive its empowerment from that of the public. Instead, there ought to be an exclusive provision on press freedom to enable the media to meet the specific mandate given to it by section 22 (Iredia 20I5).

Arguably, Oboh (20I8) established that the only additional Freedom of Information Act brought to bear on the existing provisions on press freedom in the I999 Nigerian Constitution is the right that journalists have to ask a public officer to disclose the information that is at his or her disposal and which is considered to be of public interest. The same public officer relying on the provision in the section 39, sub-section 3, could decline giving the information to journalists on the ground that such disclosure would amount to a breach of other laws that are reasonably justifiable, like the law on State Security, Official Secret Act, Classified Documents, Protected Areas and others. It is also shown in the literature that the laws establishing the media in Nigeria are: News Agencies of Nigeria, NTA Acts, Voice of Nigeria Decree, National Broadcasting Commission (NBC) among others. Also, under these laws, the President is the person to appoint the chief executive in these media. In a few cases, there is a representation of the professional association to appoint members to represent others. Therefore, in a situation whereby the President is to appoint the chief executive, the expectation is likely to be that the media will dance to the tune of the controller. Yes, the media may be able to enjoy some level of freedom but such freedom may not be absolute. Thus, the situation of the media in Nigeria regarding freedom of expression is as if using the left hand to retrieve what has been given by the right hand. 


\section{Interrogating Nigerian Media and the Military Administrations}

The relationship that existed between the mass media and the military administrations is best described in the words of Okoye (2003) as a "cat and mouse affair." Several reasons accounted to this description, among which are the mutual distrust from both parties, too much government secrecy, corruption of government officials, refusal of government to take the media into confidence on matters of national interest, and undue restrictions imposed by the government through obnoxious legislations and extra-judicial actions to curb what government perceived as the pull-him-down tendency of the press (Suntai, Agbu, and Targema 20I8).

The Nigerian media had their worst experiences during this era (Targema and Ayih 20I7). It was an era characterized by the presence of several repressive and obnoxious decrees to gag or muzzle the press. Inhuman treatments such as physical assault, harassment and molestation of journalists; arrests, detention and in some cases, killing of journalists; confiscation or proscription of issues of publications as well as a clamp down on media houses became the order of the day. Celebrated cases include: the arrest, flogging and shaving of Minere Amakiri by military personnel in I974; the arrest and jailing of Tunde Thompson and Nduka Irabor in I984; and the killing of Dele Giwa through a parcel bomb in I986. Suntai, Agbu, and Targema (2018) note that there were many editors and news reporters who were in and out of police custody between I966 and I984 no matter how brief their stay with the police.

The subsequent military regimes were no exceptions to this. In fact, if anything, they were worst in their relationship with the press. Several media houses were closed down during General Babangida and Abacha regimes. In the words of Abayomi (2003) General Abacha's regime clamped down on newspaper houses at will, proscribed publications, seized magazine copies, jailed many newsmen on allegations of taking part in coup plotting. Some of the repressive decrees enacted to restrict the press by the various military regimes include: Newspaper Prohibition from Circulation Act of ig67, Public Officers Protection against False Publication Decree No II of I976, Public Officers Protection against False Publication Decree No. 4 of I984, Detention of Persons Decree No. 2 of I984, Newspaper Registration Decree No. 44 of I993 among several others (Abayomi 2003).

According to Suntai, Agbu, and Targema (2018), these decrees constituted stumbling blocks to journalists, as they were, on several occasions 
invoked to deliver severe penalties to defaulters. Noting this point with great bitterness, Oyebode, as cited in Suntai, Agbu, and Targema (20I8), established that, indeed, the Abacha years were a seemingly unending saga of invasions, vandalization, shutdowns, false accusations, arrests, detention without trial, show trails, forced exiles, and countless heinous crimes against people wielding weapons not more lethal than their pens, recorders or laptops. This was the fate of the press during the era of the militarization in Nigeria.

\section{Nigerian Press under Democratic System}

Empirical evidence by Suntai, Agbu, and Targema (20I8) show that Nigeria had two previous experiences with civilian rule before the present dispensation - i.e. the First Republic, 1960-1966, and the Second Republic, I979-1983. Bye-and-large, the press-state relationship with civilian rulers has been better off. For example, a study by Okoye (2003) reveals that the Tafawa Balewa administration scored $40 \%$ in the index presented by the author, while Shagari and Obasanjo (second era) scored $6 \mathrm{I} \%$ and $62 \%$ respectively. When compared with the military regimes, Aguiyi Ironsi scored 43\%, Yakubu Gowon 42\%, Murtala Mohamed/Olusegun Obasanjo 4I\%, Muhammadu Buhari 26\%, Ibrahim Badamasi Babangida 32\%, Sani Abacha II\%, and Abdulsalam Abubakar 49\%; it becomes obvious that press-state relationship have been more cordial with civilian rulers. However, this discussion is more concerned with the present regime, from I999-20I9. Temegha (20II), commenting on Obasanjo's second era, notes that:

What is known about Olusegun Obasanjo's stance as a state's man was that during his eight-year Presidency, the Nigerian press and Nigerians in general enjoyed a dint of freedom. The press was free for expression and the people free for association (Temegha 20II, 47).

This may sound like sycophancy but a critical observation and comparative analysis of the media-state relationship under military rule with the present era clears every doubt. Sambe (2008) holds a similar view when he notes that, since the sudden death of the despot (Abacha) and the subsequent takeover of the reign of Government by General Abdusalami Abubakar who eventually handed over to an elected government, there has been some kind of reprieve for the media. Okoye (2003) observed at the early stage of the democratic system that: 
Two years on, the Obasanjo administration has bent backwards to deliver Nigerians the "dividends of democracy". The administration has also considerably rebuilt cordiality with the media which had borne the major brunt of military misrule over the years. Freedom of expression has blossomed once again (Okoye 2003, 7).

There were sighs of relief during the transition to civilian rule as most of the repressive decrees were being repelled, with media-state relationships seemingly more cordial. However, a careful observation of media-state relationship, especially with regard to the treatment of journalists, indicates that freedom of expression was not fully guaranteed during the first and second terms of Chief Obasanjo. Instances abound where journalists clashed with security agents and in some cases they were severely dealt with even in the democratic system. Ekuma (2012) established that, instead of the succeeding democratic regime to depart from humiliating and oppressing men of the press and as well confer freedom of expression and information on the press, without constraints, contrary is the case some journalists' experience in the country in the democratic era is still worrisome.

In the same perspective, Olaide (20II) notes that unlawful attacks on journalists and media organizations are very common in Nigeria despite the advent of civilian rule in I999. Incidents such as physical assaults on journalists, seizure or destruction of journalistic equipment, raids on or sealing up of media offices and confiscation of publications are still manifest. Idumange (2013) cites the following as a selection from hundreds reported in the media and collected in Media Right Monitor, an organ of the Media Right Agenda: beating up of Suleiman Osasuji, a sport journalist with All Sports newspaper on the I4th of October, 2003; assault, arrest, and detention of Savannah Peters, a reporter with Island News by soldiers from the 8Ist Division Garrison, Dodan Barracks, Ikoyi on May I7th, 20I4; the arrest of Segun Omolehin, Kogi State chairperson of NUJ by police in Lokoja on 22nd June, 2005; the raiding of DAAR Communication Limited in Abuja on I4th May, 2006 by state security agents to seize a master tape of a documentary, arrest and detention of Fiddis Mbah, of the BBC and Tade Oludayo of Silver Bird Television on Ioth January, 2008 by security operatives among several other cases (Olaide 20II; Idumange 2013).

Aside from these cases, the reluctance of Obasanjo's administration to sign into law, the Freedom of Information Bill did not go down well with the struggle to expand the frontiers of press freedom, although there was serious improvement on the struggle. The short-lived Yar'Adua/Jonathan administration has no serious record regarding the press and can be scored 
positively for facilitating freedom of expression. In May 20II, President Goodluck Jonathan signed into law the Freedom of Information Act. This is adjudged as a positive feat in the struggle to actualize press freedom, as the act gives impetus to journalists and members of the civil society to probe deep into issues that are within the public domain.

President Muhammadu Buhari has continued in this spirit. From his inception in 2015 to 2019 , the administration reiterated its commitment to guarantee freedom of expression. However, the menace of hate speech that increases in the country by the day has necessitated several attempts by State forces and concerned agencies to reassess the debates surrounding freedom of expression. Top on the agenda of the government is the need to curb hate speech in the mainstream media and on the various social media platforms. Efforts in this direction include the bill to establish an independent national hate speech commission and the social media bill. Although these bills are still being debated in the National Assembly, the extent to which they will limit freedom of expression is glaring, as they contain grave penalties for defaulters that, if eventually passed into law and fully implemented, can go a long way to limit freedom of expression. The paper points out that these are retrogressive steps towards the actualization of freedom of expression in the country. The demolition of facilities of Breeze FM Lafia in 2017 also counts against the struggle towards a fuller actualization of freedom of expression, although the exercise was trailed by a series of controversies, claims and counterclaims. Below are some of the demolition pictures.

\section{Figure 1: Pictures of Breeze FM Lafia, demolished by the Nasarawa State Urban Development Board}

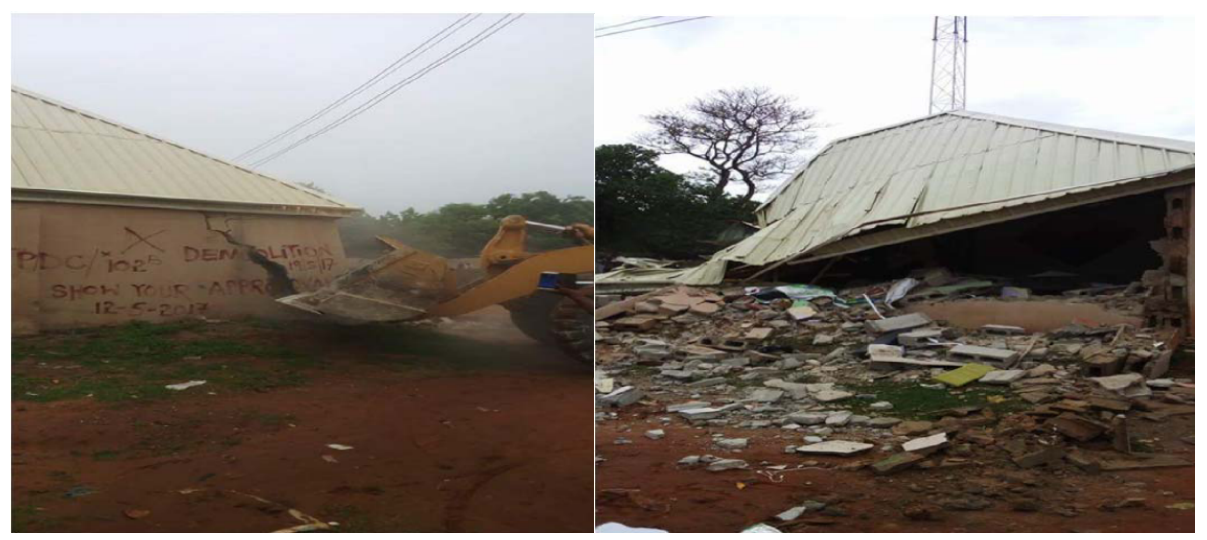

Source: (Suntai, Agbu, and Targema 20I8). 


\section{Discussion on the Situation of Press Freedom in Nigeria}

Oyeleye (2004) explored the turbulent relationship between the press, the political process and political actors in the context of the complex structure of Nigerian society. The popularity of press organizations in Nigeria began in 1859 when Henry Townsend established the first known newspaper (Iwe Iroyin) in Abeokuta, Western Nigeria (Akinwale 2010). In I863, Robert Campbell established another newspaper (The Anglo-African) which served as a channel for promoting "the interaction between Britain and Africa". Both newspapers set the stage for the emergence of flourishing indigenous press organizations, with the establishment in I880 of the Lagos Times and the Gold Coast Colony Advertiser by Richard Beale Blaize. The success of the Lagos Times inspired the emergence of several other newspapers. Chief Remi Aboderin established The Punch newspaper in I973, followed by other publications including National Concord (I980), Business Concord (1982), The Guardian (1983), African Concord (1984), African Economic Digest (1988), Hints (1989), Weekend Concord (1989), Tell (I991), Tempo (1993), The News (I993), P.M News (1994), The Week (1994), This Day (I995), among others (Akinwale 20I0). The electronic media in Nigeria started up in the I950s with the establishment of Western Nigeria Television, followed by a proliferation of radio and television stations across the country.

Ukaegbu (2007) is of the view that different press organizations have brought the deplorable state of Nigerian society to public knowledge. They have used critical journalism to expose issues ranging from poverty and crime to bad roads and other shortcomings in Nigerian cities. One newspaper vividly captured the plight of commuters on a federal road, stating that the hopeless and helpless countenance of Nigerians detained uncomfortably against their will painted a picture of a flock of sheep without a shepherd (Leba 2006). The relationship between the press and Nigerian governments has often been largely antagonistic. It started from mild restrictions of press freedom during the colonial era and grew into full-blown repression in the post-colonial era. With the establishment of state media and press censorship, the Nigerian press became weak, partisan and ethnocentric. Successive governments employed the press as an instrument of propaganda (Akinwale 20I0). The Nigerian Press Organisation attempted to effect changes in the National Mass Media Commission (NMMC) after the I999 general elections but to no avail. The NMMC defines lawful information and balanced reporting in the light of the interests of the state. Similarly, the Newspaper Registration Decree mandates a non-refundable fee of one hundred and fifty thousand

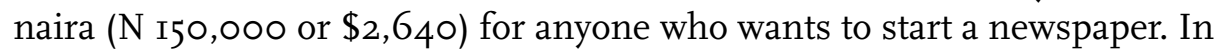


I984, the Nigerian government published Decree 2, which empowered the Inspector-General of Police to detain indefinitely and without trial any person considered as a risk to state security (Akinwale 2010).

Ojo (2006) established that the government used Decree 60 to establish the Nigerian Press Council (NPC) in I999 and charged it with the enforcement of professional ethics. Immediately, the Nigerian Union of Journalists (NUJ) and the Newspaper Proprietors Association of Nigeria (NPAN) rejected the creation of the Press Council because the decree contained a number of provisions perceived to be inimical to the operation of a free press. The NPC was empowered to accredit and register journalists. In applying for registration, publishers were expected to submit their mission statements and objectives and could be denied registration if their objectives failed to satisfy the NPC. The penalties for operating without meeting the Council's standard were a fine of $\mathrm{N} \mathrm{250,000}(\$ 2,500)$ or three years' imprisonment. The review made above drives the significance of the Libertarian Theory as anchored in this paper.

Libertarian Theory emerged in Europe in the I7th century, in opposition to the Authoritarian Press Theory. This was the period when Monarchs ruled most of Europe with a series of anti-press laws that were aimed at restricting freedom of expression. Proponents of the theory such as John Milton, John Stuart Mill and John Locke advocated for "a free marketplace of ideas" where both good and bad ideas will float freely, with the conviction that good ideas will naturally "sell" and be preferred by the masses at the expense of the bad ones (McQuail 2005; Sambe 2008; Nwabueze 20I4). As a result, any limitation to freedom of expression (formal or informal) violates the tenets of this press theory. The theory is a normative theory; hence, it serves to explain the workings of the media within the operational environment. Though a relatively old press theory, libertarianism is not fully attained in most of the post independence African democracies. This is not far-fetched from reality as a series of military dictatorships thrived in most of the post-independence African States, where authoritarian principles were held with high esteem in a bid to muzzle the press, and by extension the civil society, so as to have a firm grip on power. Libertarianism was, therefore, an unaffordable luxury. However, with militarization now a thing of the past, there is a tendency that the new democracies would allow some space for libertarianism to thrive in the media.

Taking other countries side by side with Nigeria, in the United States of America, for example, the First Amendment to the Constitution specifically provides that Congress shall make no law restricting the press. Although the 
courts have long struggled in that country to determine whether the framers of the Constitution intended to differentiate press freedom from speech freedom, some legal scholars, including Justice Potter Stewart, of the U.S. Supreme Court, have persuasively advocated for special press protections distinct from those accorded to speech. In Ghana, Section I62 (4) of the nation's Constitution expressly empowers the media to function. In the words of the section, editors and publishers of newspapers and other institutions of the media shall not be subject to control or interference by government nor shall they be penalized or harassed for their editorial opinions and views or contents of their publication. In Malawi, Section 36 of the Constitution provides that the media shall have the right to report and publish freely, within Malawi and abroad, and to be accorded the fullest possible facilities for access to public information. The situation in Malawi is probably the most apt as the country provided for freedom of expression in section 35 of its Constitution and moved just one step ahead to provide for press freedom in section 36 .

Therefore, Malawi and other countries which have specific provisions for media freedom in their constitutions, notwithstanding that there is a general provision for freedom of speech, have established beyond reasonable doubt that press freedom and freedom of speech are not coterminous. If, therefore, the media in the USA, Ghana, Malawi and some other countries are more courageous in their facilitation of social change in their countries, the statutory support they have cannot be wished away. In Nigeria, on the other hand, there is ample evidence that the media is not free. It is in earnest obvious from the Acts, Laws and Regulations which govern media practice in the country that there has always been an overzealous official policy to legally gag the media. The trend in fact dates back to the colonial era when the Newspaper Ordinance of I903, the Sedition Ordinance of I909 and the Criminal Code of I9I 6 came into being. One of the early steps of the colonial governor, Frederick Lugard, after the amalgamation of the Northern and Southern Protectorates of Nigeria was to consolidate all existing Acts to enact the Newspapers Act of I9I7 for the sole purpose of regulating the existence of Newspapers through the process of registration.

The Act was amended in 1964 to accommodate government-owned newspapers, which did not exist before then, and in 1993 it was amended again to increase penalties for breaching any provisions of the Act. Other laws which govern media practice in Nigeria such as those on Sedition, Pornography, Official Secrets, Copyright and Defamation were similarly enacted essentially to repress the press and prevent criticism of the government in power (Iredia 20I5). In the case of the law of defamation, some media professionals think that the law can make the nation's media timid because it 
provides for a greater penalty for the media used than the person who actually committed the offence. Indeed, as far back as I96I, the Supreme Court of Nigeria had held that the mass media have no special immunity; they must bear full responsibility for their actions (Momoh 2004). The media is also virtually liable for only the more serious dimension of defamation or libel and not slander because every defamatory act in the media being in permanent form requires no special proof and, as the lawyers say, is actionable per se.

In Nigeria, journalists are also occasionally confronted with issues like Contempt of Court. In 20I2, for instance, a magistrate court judge ordered the police to arrest and detained seven judiciary correspondents in Lagos, South West Nigeria. The judge accused the journalists of allegedly disturbing court sessions with their cameras and phones, as they were said to be busy clicking for exclusive pictures, which eventually angered the judge, who handed down the order. Based on the directive, which was interpreted as Contempt of Court, the journalists were moved from the court premises at Ikeja GRA to Area F police command for eventual detention (Udom 20I2).

In addition to the laws, there are also several regulatory bodies, such as the Nigerian Press Council, the National Broadcasting Commission, the Film and Video Censors Board and the Copyright Commission, set up essentially to put the media in check all the time. In the case of the Nigerian Press Council (NPC), which regulates the print media, it is set up supposedly to protect both the public and the press but it is difficult to find an example of the NPC ever standing on the side of media operatives, despite the numerous attacks on them in Nigeria. Interestingly, no media professional expects the council's protection in view of the judicial decision that its enabling law is oppressive, overbearing and grossly not compatible with the standard of a society (Iriekpen 20IO). On its part, the National Broadcasting Commission (NBC), which regulates broadcasting in the country, penalizes only the opposition media and for frivolous reasons too. In 2009 , it took the courts to save Adaba FM 88.5 Radio, an Akure based station, from the claws of the regulatory body. According to Sowole (2009) the decision of the NBC to shut the station was reversed by Justice C. Okeke of the Federal High Court Akure who upheld the plea of the station that the NBC breached its constitutional right to fair hearing, freedom against discrimination, and freedom of expression.

As for the public media, their enabling laws are equally restrictive leaving the operatives with little or no room for personal initiative and discretion. For instance, the Nigerian Television Authority Act, which sets up the main public television broadcaster, says in its section I2 that the Minister may give the Authority directions of a general character or relating generally 
to political matters with regard to the exercise by the Authority of its functions under this act, and it shall be the duty of the Authority to comply with such directions (Iredia 20I5). The same provision which is reproduced in the laws setting up the Federal Radio Corporation of Nigeria and the Voice of Nigeria has turned out to be the basis for which the organizations are now and again professionally misdirected especially to manipulate their news bulletins (Iwokwagh 2005). Perhaps some of the media laws and regulations so far identified fall into the category which section 45 of Nigeria's Constitution says may be reasonably justifiable in a democratic society in the interest of defence, public safety, public order, public morality or public health, or for the purpose of protecting the rights and freedom of other persons but their implementation as shown above are often inimical to media practice in Nigeria.

Apparently, like every other profession, the media certainly has its bad eggs that are engaged in sensationalism, inaccurate reporting, corrupt practices and other vices. It also has a plethora of constraints; among them are ownership control, poor salaries, as well as inadequate human and material resources. These notwithstanding, the media can be exceedingly useful to society because it is the most effective organ of public enlightenment which can empower the people to be rational, wise and useful to themselves and society. Fortunately, since 20II Nigeria has joined those countries which operate a freedom of information regime which can assist the media to further educate the public. It is however unfortunate that the Freedom of Information Act (20II), which provides for unhindered access to public information, has not substantially changed the situation because the modalities for implementing the law are yet to be institutionalized. Going by the posers of whether Nigerian media have the teeth to bite as far as freedom of expression is concerned or the provisions are just give-and-take documents, the paper submits that, actually, it is a give-and-take document and Nigerian media have no teeth to bite as far as freedom of expression is concerned as it is evidence in the literature. Freedom of expression in Nigeria is a mere myth.

\section{Conclusion}

For democracy to be strengthened, the media have a very big role to play. Within this context, the paper submits that, for the media to facilitate the goal of development, national interest must be put first in order to achieve national objectives which will pave the way for political realism. The media must project the interest of the nation while carrying out their social responsibilities. National interest must be highly recognised by the media and must 
remain a big priority. As the Fourth Estate of the Realm, the media must strive to play their role in the agenda more effectively by ensuring that they raise the level and quality of public debates on issues of national interest. The paper concludes that the media are the essential ingredients for governance and for democracy to be strengthened; freedom of expression must be guaranteed to the media in reality. No constitution is sacrosanct when there is the need to make useful amendments on the existing laws. In the alternative, the provision in Section 39, Sub-section 3 of the I999 Nigerian Constitution should be expunged to enable the media to enjoy the entitlements provided in Section 39, Sub-Section (I) and (2). Accordingly, the paper renews the appeal of Pate (20I5) calling on the media to understand the complexities of the nation in order to develop common national platforms in reporting and the ability to be guided by the national interest or spirit in all cases. Paraphrasing the words of late Professor Weiner, the media must understand that to build a nation, it takes centuries; to destroy it, it takes only a day or two.

\section{References}

Abayomi, S. 2003. "Government-media relationship from I960-2000". In Issues in Nigerian media history 1900-2000, edited by R. Akinfelaye and I. Okoye. Lagos: Malthouse publishers limited

Akinwale, A. A. 20I0. "Repression of press freedom in Nigerian democratic dispensations." Africa Development 35 (3): 47-70.

Ekuma, C. 2012. "Press freedom in Nigeria: Rundown I960-2012". Chinet. Accessed November I8, 2020.

Idumange, J. 2013. "Freedom of expression in Nigeria: navigating a meeting point between the old and new media." The Nigerian Voice. https:// www.thenigerianvoice.com/news/II3184/freedom-of-expression-in-nigeria-navigating-a-meeting-point.html

Iredia, T. O. 20I5. "The media and the law in Nigeria." Journal of Humanities And Social Science 20 (12): 30-36.

Iriekpen, D. 2010. "Nigeria: Court declares press council law oppressive". This Day Online. Accessed September 28, 20I5. www.thisdayonline. com/nview.php

Iwokwagh, N. 2005. The politics of Nigeria's fourth republic and government owned broadcast media: The issue of news manipulation. Makurdi: Aboki Publishers 
Jibo, M., and A. Simbine. 2003. Contemporary issues in Nigeria. Ibadan: JODAD Publishers.

Leba, L., 2006. "Ore-Benin road: metaphor of a failed social contract". Vanguard, Lagos, Nigeria, 23 October.

McQuail, D. 2005. Introduction to mass communication theory. London: Sage Publications.

Momoh, T. 2004. Nigerian media law and ethics. Lagos: Pugmark Nig. Ltd. (Educational Publishers).

Nwabueze, C 20I4. Introduction to mass communication: Media ecology in the global village. Owerri: Topshelve Publishers.

Nwanne, B. U. 20I4. "Another look at press freedom in Nigeria". European Journal of Research in Social Sciences 2 (4): I-II.

Oboh, G. E. 20I8. "Political economy of media operations in Nigeria: Nigerian political culture and the media in global spectrum". In Political economy of the media, pp. 22-38. Edited by Popoola, M. and G. E. Oboh. Oyo: Franco-ola Printers.

Ojo, E.O. 2006. "Human rights and sustainable democracy in Nigeria". Journal of Social Sciences I3 (I): 15-29.

Okoye, I. 2003. "Historical overview and analysis of government-media relationship in Nigerian from I900-200I". Pp. I02-II3. In Akinfelaye, R. \& Okoye, I. (eds) Issues in Nigerian mediahistory: 1900-2000 $A D$. Lagos: Malthouse press limited.

Okoye, I. 2003. "Historical overview and analysis of government-media relationship in Nigerian from I900-200I". Pp. I02-II3. In Issues in Nigerian media history 1900-2000 AD, edited by R. Akinfelaye and I. Okoye. Lagos: Malthouse publishers limited.

Olaide, F. 20II. "The Nigerian press: the journey so far". Continental journal of Sustainable Development. Vol. 2(I). Pp. 8-I9

Oyeleye, A. 2004. "The mediation of politicians and the political process in Nigeria". Parliamentary Affairs 57 (I): I57-I68.

Pate, A. U., and H. Idris. 20I7. "How journalists survive to report: Professionalism and risk management in the reporting of terror groups and violent extremism in North East Nigeria". In The assault on journalism building knowledge to protect freedom of expression, edited by Carlsson U., and R. Pöyhtäri. Sweden: Nordicom. 
Pate, U. 20I7. "Professionalizing and risk management in the reporting of terror groups and violent extremism in the North East Nigeria, 2009-20I5: How journalists survived to report" In Multiculturalism, diversity, reporting conflict in Nigeria, edited by Pate, U. A., and L. Oso, I33-I56. Ibadan: Evan Brothers Nigeria Publishing Limited.

Pate, U. 2015. Issues in media and national integration in Nigeria. Lagos: African Resource Communications Ltd.

Sambe, J. 2008. Introduction to mass communication practices in Nigeria. Ibadan: Spectrum

Sowole, J. 2009. "Nigeria: Court Orders NBC to Reopen Radio Station". This Day Newspaper, May I3.

Suntai, D.I., A. D. Agbu, and T. S. Targema. 2018. "Mass media, freedom of expression and democracy: the Nigerian experience from I99920I7". TSU Journal of Communication and Media Studies I (I): 2-I3.

Targema, T. S., and L. J. Ayih. 20I7. "Nature and System of Media Ownership and Control in Nigeria: Implication for Grassroots Participation and Development". Nairobi Journal of Humanities and Social Sciences (NJHS) I(7): 53-65.

Temegha, S. O. 20II. "Olusegun Obasanjo: The personality and philosophy of a president". Pp. 22-39. In Obasanjo Second Era: 1999-2007, edited by Wuam, T., S. T. Olali, and J. Obilikwu. Makurdi: Aboki Publishers.

Udom, E. 20I2. "Why Judge ordered police to arrest 7 journalists". The Nation Newspapers, April 4

Ukaegbu, C.C. 2007. "Leadership fatalism and underdevelopment in Nigeria: imaginative policymaking for human development". Philosophia Africana Io (2): I6I-I82.

\section{ABSTRACT}

In all civilized societies, the media stand as an independent institution that checks the activities of the people and the government. In Nigeria, apart from the executive, the judiciary and the legislature, the media are regarded as the Fourth Estate of the Realm. From the Universal Declaration of Human Right, Article is provides freedom of expression as part of fundamental human rights. At the level of AU in Africa, the right to freedom of information and freedom of expression was also given due consideration especially in Article nine. The Nigerian Constitution of I 999 also guarantees the freedom of expression, specifically Section 39 of the Constitution which assigns a constitutional right, power, role, obligation and duty to the press. 
Nigerian Constitutions since then have upheld this role. Section 22 of the same Constitution recognises the media as the "Fourth Estate of the Realm". It therefore means the media are seen as an oversight of the government and its agencies. The Freedom of Information Act establishes that information should be made available and that the citizens should feel free to express their personal views. Thus, in order to achieve the objectives of this paper, the following serve as the basic tools of inquiry: do Nigerian media have the teeth to bite as far as freedom of expression is concerned? Or the proceeding provisions are just give-and-take documents? These questions are the main focus of this paper. The paper employs a multidisciplinary research methodology using a combination of socio-legal methods to obtain the contextual data. In addition, selected pertinent judicial decisions in law reports and journals were reviewed to examine the freedom of expression. The paper also critically examined non-legal sources for investigative or supporting information. Among the technical documents reviewed are: The Constitution of the Federal Republic of Nigeria 1999; Freedom of Information Act among others.

\section{KEYWORDS}

Accountability. Freedom of expression. Governance. National interest. Nigerian media. 